\title{
SITE DIRECTED MUTAGENESIS OF THE MURINE CORONAVIRUS SPIKE PROTEIN
}

\author{
Effects on Fusion
}

\author{
E. C. W. Bos, L. Heijnen, and W. J. M. Spaan \\ Institute of Virology, Faculty of Medicine \\ University of Leiden \\ The Netherlands
}

\begin{abstract}
Mutations were introduced in the transmembrane region of the spike protein of the murine coronavirus A59. The maturation of these mutant S proteins was not affected, they were all expressed at the cell surface, and became acylated, however some mutant $\mathrm{S}$ proteins did not induce cell-to-cell fusion. An $\mathrm{I} \rightarrow \mathrm{K}$ change in the middle of the predicted transmembrane (TM) anchor and mutation of the first three cysteine residues of the TM domain resulted in a fusion-negative phenotype. We propose a model by which these data can be explained.
\end{abstract}

\section{INTRODUCTION}

The spike (S) protein of the murine coronaviruses has several important features. The glycoprotein has been shown to bind to the receptor on the host cell ${ }^{1}$, and is capable of inducing cell-to-cell fusion ${ }^{2}$. Furthermore the spike protein can induce neutralizing antibodies $^{3}$.

The murine coronavirus Spike protein is synthesized as a $110 \mathrm{kDa}$ core protein that is co-translationally glycosylated in the ER to become a $150 \mathrm{kDa}$ glycoprotein. During transport from the ER to and through the Golgi stacks, the protein matures to its $180 \mathrm{kDa}$ form. Subsequently, part of the molecules are cleaved into two subunits of $90 \mathrm{kDa}$ (S1 and $\mathrm{S} 2$ ). In recent years several groups have shown that cleavage of $\mathrm{S}$ is not a prerequisite for cell-to-cell fusion. However, cleaved $\mathrm{S}$ induces fusion more rapidly ${ }^{4,5,6}$.

Although it has been known for several years that the spike protein functions as a fusion protein, the fusion mechanism is still unknown. Gallagher et al. ${ }^{7}$ showed that fusion could be induced at low $\mathrm{pH}$ when mutations occurred in the first heptad repeat. Furthermore, Grosse and Siddell ${ }^{8}$ found that spike proteins that were resistant to neutralizing antibody 


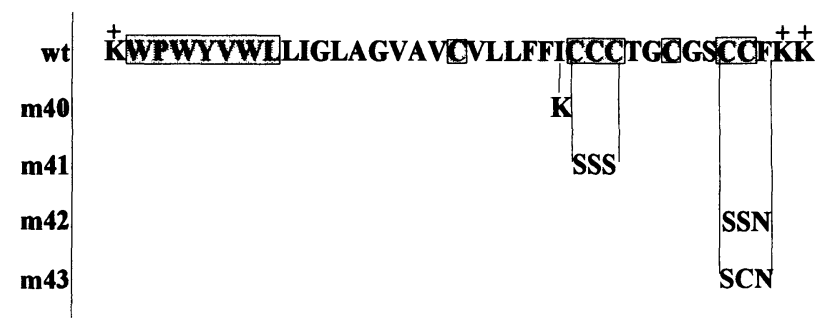

Figure 1. Schematic representation of the transmembrane anchor of the coronavirus spike protein. The amino acid sequence of the wild type protein is depicted at the upper line. For the mutants, only the changed amino acids are depicted. Charged residues at the $\mathrm{N}$ - and $\mathrm{C}$-terminus of the $\mathrm{TM}$ anchor are marked + . Conserved residues (the WYV domain and the cysteine residues) are in boxes.

$11 \mathrm{~F}$, did contain mutations in the second heptad repeat of the S2 sub-unit. This monoclonal antibody $11 \mathrm{~F}$ had previously been shown to inhibit cell fusion, but not the virus-receptor interaction ${ }^{9}$. Thus, the S2 sub-unit of the S protein is very likely to be involved in the $\mathrm{pH}-$-related conformational changes that are required for fusion. In this study we have focused on the role of the transmembrane region in cell fusion.

\section{RESULTS}

The TM anchor is defined as the region between charged residues that is potentially inserted into the membrane. The charged residue at the C-terminus of the TM anchor functions as a stop translocation signal. From a comparison of the TM anchor of all coronavirus $\mathrm{S}$ genes sequenced to date, some general features can be deduced. Firstly, at the $\mathrm{N}$-terminus of the TM seven large hydrophobic residues are located, which are conserved in all $\mathrm{S}$ proteins. Secondly, this domain is followed by 11 to 22 hydrophillic amino acids, containing several cysteines residues. The cysteine residues in this region are candidates for palmitoylation. Finally, the length of the TM domain is unusual large.

We have introduced several mutations in the TM domain as indicated in Fig.1 and analyzed the expression and the fusogenicity of the mutant $\mathrm{S}$ protein.

First, transport of the different mutants was studied. The proteins were expressed in L-cells, using the vaccinia $\mathrm{T} 7$ expression system. In a pulse-chase experiment, the endo- $\mathrm{H}$ profiles of the mutants was determined. All mutants were transported to the medial Golgi. Transport of the mutants to the trans Golgi stacks was not affected, since all mutants were partially cleaved into the two $90 \mathrm{kDa}$ sub-units (Table 1).

By using immunofluorescence it was demonstrated that all mutants were transported to the cell surface. However, not all mutants were fusogenic. M43 was as fusogenic as the

Table 1. Characteristics of the spike mutants.

\begin{tabular}{lcccc}
\hline & Cleavage & Cell surface expression & Acylation & Cell-to-cell fusion \\
\hline $\mathrm{wt}$ & + & + & + & + \\
$\mathrm{m} 40$ & + & + & + & - \\
$\mathrm{m} 41$ & + & + & + & - \\
$\mathrm{m} 42$ & + & + & + & + \\
$\mathrm{m} 43$ & + & + & + & + \\
\hline
\end{tabular}




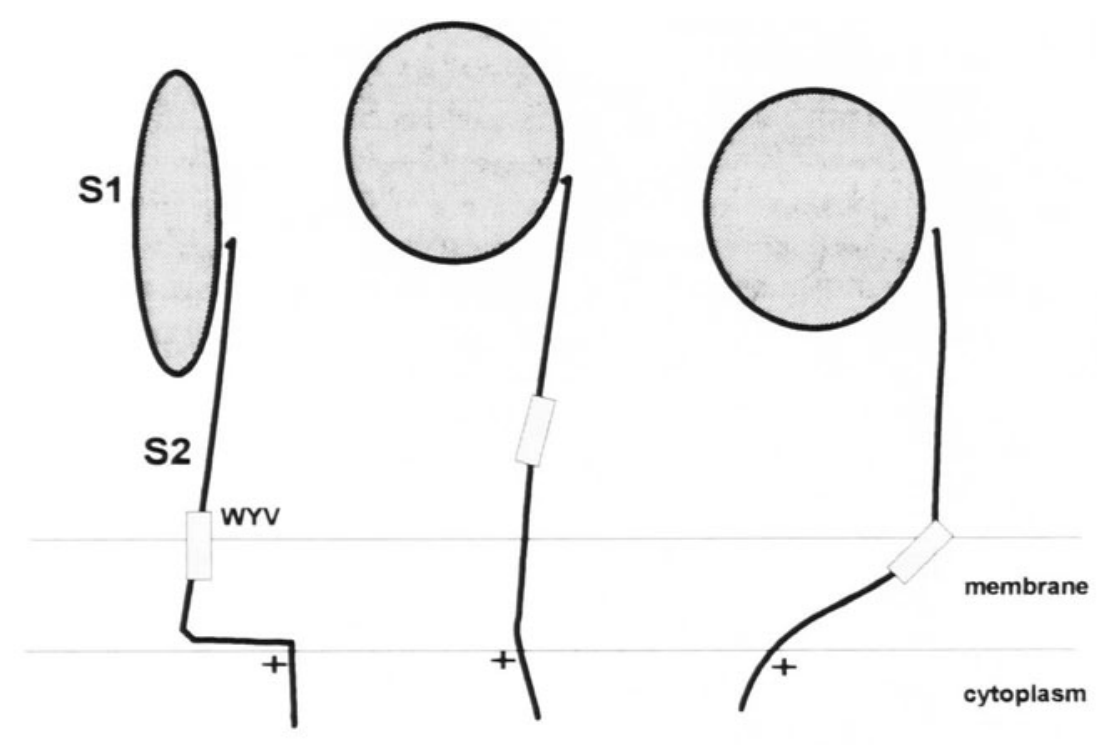

A

B

C

Figure 2. Possible models of the spike protein of MHV before (A) and after conformational changes have occurred (B and C). The S1 and S2 sub-units of the monomeric form of the spike protein are indicated. The highly conserved WYV domain is depicted as a box. The charged residue that functions as transfer stop signal is indicated by + at the cytoplasmic side of the membrane.

wild type spike protein, the fusion induced by $\mathrm{m} 42$ was delayed and the syncytia remained smaller, and $\mathrm{m} 40$ and $\mathrm{m} 41$ did not induce syncytia (Table 1).

For influenza virus, it has been shown that the degree of palmytoilation of the fusion protein can affect fusogenicity. The HA protein of some influenza strains is not fusogenic when palmytoilation is blocked ${ }^{10,11}$. For other strains, however, block of acylation had no effect on fusion ${ }^{12,13}$. To study the effect of the cysteine mutations on acylation of the murine coronavirus S protein, L-cells were labelled with ${ }^{3} \mathrm{H}$-palmitic acid, and subsequently subjected to immunoprecipitation. Unfortunately all mutants became acylated, albeit to a different extent. Mutants $\mathrm{m} 41$ and $\mathrm{m} 42$ were less acylated, suggesting that some of the cysteine residues that were changed in these mutants are involved in acylation (Table 1).

We propose a model, by which our data can be explained, Fig. 2 . We hypothesize that after binding of S to the receptor, some conformational changes in both S1 and S2 occur as indicated in Figure 2. Either, the entire protein is pulled out of the membrane, thus exposing the highly conserved WYV domain (Fig.2B). Or as depicted in Figure 2C, the TM region of $\mathrm{S}$ could be twisted in the membrane, such that it becomes inserted in a different angle. Both proposed conformational changes require a large TM domain. Due to acylation the cysteine residues become hydrophobic, and can therefore be inserted into the lipid bilayer. The proposed changes in the $\mathrm{S} 2$ domain are not possible for our mutants $\mathrm{m} 40$ and $\mathrm{m} 41$. The charged residue in $\mathrm{m} 40$ may serve as a stop-transfer signal during translocation of the $\mathrm{S}$ protein across the ER membrane. As a result the TM domain of $\mathrm{m} 40$ is fixed in the membrane. In the absence of acylation of the cysteine residues which have been mutated in $\mathrm{m} 4 \mathrm{l}$ the hydrophobic feature of the cysteine rich domain is less pronounced resulting in again a fixed 
TM domain The phenotype of our mutants indicates that both the length of the TM and a position effect of acylated cysteines might be involved in fusion

Finally, we have developed an assay by which we can test the effect of mutations in S or other structural proteins on infectivity To this end, we transfected vaccinia virus infected L cells with four different constructs encoding for S, M, N and sM As RNA, the DI-RNA ${ }^{14}$ was also introduced in the cells The release of DI RNA containg particles was analyzed by addıng helpervirus MHV A59 to the medium and infectıng a new monolayer of L-cells using this mixture Replication of the DI-RNA was analyzed following several undiluted passages

It was demonstrated that DI-RNA was only transferred to helpervirus-infected L-cells when DI-RNA was co-expressed with all structural proteins In the absence of the structural proteins no DI-RNA was observed following undiluted passage Although not proven directly, we assume that the DI-RNA which was released into the medium of the transfected cells was packaged into a virus like partıcle

\section{REFERENCES}

1 Collıns A R, Knobler R L, Powell H, Buchmeier M J Monoclonal antibodies to murıne hepatitıs virus-4 (strain JHM) define the viral glycoproteın responsible for attachment and cell-cell fusion Virology 1982,119 358-371

2 Sturman L S , Holmes K V The molecular biology of coronaviruses Adv Virus Res 1983,28 35-112

3 Flemıng J O, Stohlman S A, Harmon R C , Laı M M C , Frelınger J A Weıner L P Antigenıc relationships of murine coronaviruses analysis using monoclonal antibodies to JHM (MHV-4) virus Virology 1983,131 296-307

4 Stauber R, Pfleiderera M, Siddell S Proteolytic cleavage of the murıne coronavirus surface glycoprotein is not required for fusion activity J Gen Vir 1993,74 183-191

5 Taguch $\mathrm{F}$ Fusion formation by the uncleaved spike protein of murine coronavirus JHMV variant cl-2 J Vir 1993,67 1195-1202

6 Gombold J L, Hingley S T, Weiss S R Fusion-defective mutants of mouse hepatitıs virus A59 contain a mutation in the spike protein cleavage signal J Vir 1993,67 4504-4512

7 Gallagher T M , Escarmıs C , Buchmeier M J Alteration of the pH dependence of coronavirus-induced cell fusion effect of mutations in the spike glycoprotein J V 1991, 65 1916-1928

8 Grosse B, Siddell S G Single amıno acid changes in the S2 subunit of the MHV surface glycoprotein confer resistance to neutralization by S1 subunit-specific monoclonal antibody Virology 1994, 202 814-824

9 Routledge E, Stauber R, Pfleıderer M, Siddell S G Analysis of murıne coronavirus surface glycoprotein functions by using monoclonal antibodies J V 1991, 65 254-262

10 Naeve C W, Willıams D Fatty acids on the A/Japan/305/57 influenza virus hemagglutının have a role in membrane fusion EMBO J 1990,9 3857-3866

11 Lambrecht B, Schmidt M F G Membrane fusion induced by influenza virus hemnagglutının requires protein bound faaty acids FEBS 1986,202 127-132

12 Veit M, Kretzschmar E, Kuroda K, Garten W, Schmidt M F G, Klenk H D, Rott R Site-specific mutagenesis identıfies three cysteine residues in the cytoplasmic tail as acylation sites of influenza virus hemagglutinin J V 1991, 65 2491-2500

13 Steınhauer D A, Wharton S A, Wiley D C, Skehel J J Deacylation of the hemagglutının of influenza A/Aichi/2/68 has no effect on membrane fusion properties Virology 1991, 184 445-448

14 Van der Most R G, Bredenbeek P J, Spaan W J M A domain at the 3' end of the polymerase gene is essential for encapsidation of coronavirus defectıve interfering RNAs J V 1991, 65 3219-3226 